\title{
Fast and reliable detection of toxic Crotalaria spectabilis Roth. in Thunbergia laurifolia Lindl. herbal products using DNA barcoding coupled with HRM analysis
}

\author{
Sahachat Singtonat and Maslin Osathanunkul
}

\begin{abstract}
Background: Nowadays, medicinal plants are used as a popular alternative to synthetic drugs. Many medicinal plant products have now been commercialized throughout various markets. These products are commonly sold in processed or modified forms such as powders, dried material and capsules, making it almost impossible to accurately identify the constituent species. The herbal plant known as 'Rang Chuet' in Thai has been widely used as remedies for various ailments. However, two medicinal plants species, Thunbergia laurifolia and Crotalaria spectabilis share this name. Duo to the similarity in nomenclature, the commercial products labeled as 'Rang Chuet' could be any of them. Recently, the evidence of hepatotoxic effects linked to use of $C$. spectabilis were reported and is now seriously concern. There is a need to find an approach that could help with species identification of these herbal products to ensure the safety and efficacy of the herbal drug.

Methods: Here DNA barcoding was used in combination with High Resolution Melting analysis (Bar-HRM) to authenticate T. laurifolia species. Four DNA barcodes including matK, rbcL, rpoC and trnL were selected for use in primers design for HRM analysis to produce standard melting profiles of the selected species. Commercial products labeled as 'Rang Chuet' were purchased from Thai markets and authentication by HRM analyses.

Results: Melting data from the HRM assay using the designed primers showed that the two 'Rang Chuet' species could easily be distinguished from each other. The melting profiles of the all four region amplicons of each species are clearly separated in all three replicates. The method was then applied to authenticate products in powdered form. HRM curves of all ten test samples indicated that three of the tested products did not only contain the T. laurifolia species.

Conclusion: The herbal drugs derived from different plants must be distinguished from each other even they share the same vernacular name. The Bar-HRM method developed here proved useful in the identification and authentication of herbal species in processed samples. In the future, species authentication through Bar-HRM could be used to promote consumer trust, as well as raising the quality of herbal products.
\end{abstract}

\section{Background}

\section{Herbal medicines}

Natural products from plants have played a considerable role in the way of life of people around the world since ancient times. Plant products have been consumed as food and used as medicinal remedies. An enormous number of scientific reports highlight the benefits of

\footnotetext{
* Correspondence: omaslin@gmail.com
Department of Biology, Faculty of Science, Chiang Mai University, Chiang Mai

*Correspondence: omaslin@gmail.com
Department of Biology, Faculty of Science, Chiang Mai University, Chiang Mai 50200, Thailand
} C Biomed Central

(C) 2015 Singtonat and Osathanunkul; licensee BioMed Central. This is an Open Access article distributed under the terms of the Creative Commons Attribution License (http://creativecommons.org/licenses/by/4.0), which permits unrestricted use, distribution, and reproduction in any medium, provided the original work is properly credited. The Creative Commons Public Domain Dedication waiver (http://creativecommons.org/publicdomain/zero/1.0/) applies to the data made available in this article, unless otherwise stated.

using medicinal plants and herbs as an alternative to modern synthetic drugs [1]. It is clear that medicinal plants are a popular alternative to synthetic drugs. According to the World Health Organization [2], over 70\% of the world's population in developing countries uses herbal products. Many medicinal plant products have now been commercialized. These products are commonly sold in processed or modified forms such as powders, dried material, tablets, capsules and tea bags, making it almost impossible to accurately identify the constituent species [3-5]. Because of this, consumer 
safety could be a concern. Misidentification of the constituent plants may lead to the inclusion of undesirable, unrelated species, with a potential health risk to the end users. Substitution of the product's ingredients either intentionally or inadvertently can have negative effect on both consumers and producers. Because of these identification issues, any measures that may aide in the identification of herbal products would be beneficial. Many species from the Acanthaceae family are considered in Thailand to have health benefits, several species (Acanthus ebracteatus, Andrographis paniculata, Rhinacanthus nasutus and Thunbergia laurifolia) are now included on the Thai National List of Essentials Medicine (NLEM; Thailand). These Acanthaceae species are commonly used in Thai household as remedies for various ailments and thus are regularly sold on the markets throughout Thailand. There is a need to find an approach that could help with the quality control of these herbal products to ensure both the satisfaction and safety of consumers.

Thunbergia laurifolia is one of common Thai medicinal plant with various used such as antipyretic, detoxification against insecticides, alcoholic and metallic poisons. T. laurifolia commonly known in Thai as 'Rang Chuet' has been used in Thailand as a natural remedy for decades. Commercial products of 'Rang Chuet' in tea, capsule, and powder forms in herbal markets are claimed to have beneficial effects on human health. However, confusion has arisen because of the similarity in the vernacular names of the plants. In Thailand, there are at least three species are being called 'Rang Chuet', one of these is Crotalaria spectabilis. There are several documentations reported that seeds and leaves of $C$. spectabilis contain pyrrolizidine alkaloids which causes Hepatotoxicity in humans and mammals [6-10]. Due to the fact that, Rang Chuet was immensely sold in Thailand local markets and used as household remedy in form of processed products. Therefore it is almost impossible for consumer to know exactly which 'Rang Chuet' products they are buying so this could be a real big issue and is now seriously concern.

\section{Molecular species identification}

Recently, many works have been focused on authentication or detection of species substitution of herbal products. Molecular techniques like RFLP and RAPD were developed for Rang Chuet identification [4, 5]. Both RFLP and RAPD technique showed a potential in discrimination of the two Rang Chuet (T. laurifolia and $C$. spectabilis) species but the disadvantage of RFLP is not only relatively time consuming but the RFLP also requires a large amount of sample, although RAPD technique is fast but many [11-14] show unstable results and sometimes unreproducible.
In the past decade, DNA barcoding (short DNA sequence) is proved to be useful for identifying and categorizing species [15]. To date, several Rang Chuet barcodes from various plastid genome regions including mat $K$, $r p l 16, \operatorname{rps} 16, \operatorname{trnL}$ and $r b c L$ were produced [5, 14]. Although DNA barcoding is proven useful for species-level identification of plants $[16,17]$, there are some limitations to the technique. It is costly and time-consuming, and not easy to apply routinely in developing countries due to financial constraints and limited availability of perishable chemicals and consumables. This leads us in searching for new fast, reliable, less time consuming and inexpensive method for species identification and authenticating of medicinal plants. Here we applied DNA barcoding with high resolution melting (Bar-HRM) analysis for species identification and authentication of 'Rang Chuet' products sold on Thai markets. The use of Bar-HRM for taxonomic identification and the detection of adulteration in food and agriculture products has been reported recently [18-20]. In this study we evaluate whether the technique is equally useful for species discrimination in constituents of Thai folk medicinal plant.

\section{Materials and methods}

\section{Primers used for HRM analysis}

Sequences of the plastid DNA regions, matK, rbcL, rpoC and trnL of selected medicinal plants from the family Acanthaceae (Thunbergia spp.) and Fabaceae (Crotalaria spp.) were extracted from GenBank (at the end of September 2013) using the key phrases "the name of locus" and "the name of species" in the annotations. Generally, sequences obtained from public databases, including GenBank, are of low quality with no known associated herbarium vouchers. For this reason, all of the sequences were subjected to critical evaluation and any low-quality sequences were removed. After processing, multiple alignments were made from the selected sequences using MEGA6 [21] and variable characters were calculated for the design of primers to be used for high resolution melting (HRM) analysis. Two main criteria were considered in order to obtain successful results in the HRM analysis: (i) the primer pair should generate a PCR product not exceeding $300 \mathrm{bp}$, (ii) the primer pairs should cover enough variable sites to enable discrimination among the tested species and any other variation site from sequence of conspecifics.

\section{Plant samples and DNA isolation}

Both fresh and dried samples were included in this study (Table 1). Two 'Rang Chuet' herb species (T. laurifolia and $C$. spectabilis) were the main focus of the study. Fresh specimens of these species were collected from areas in Chiang Mai province, Thailand. Dried plant tissues for DNA extraction were kindly provided by Queen 
Table 1 Plants species and commercial products included in this study

\begin{tabular}{|c|c|c|c|}
\hline Species/Type & Abbreviation & Source & Sample type \\
\hline \multirow[t]{2}{*}{ Thunbergia laurifolia } & \multirow[t]{2}{*}{$\mathrm{T} 1$} & Materia Medica garden & \multirow[t]{2}{*}{ Fresh } \\
\hline & & Faculty of Pharmacy, Chiang Mai University & \\
\hline \multirow[t]{2}{*}{ Thunbergia laurifolia } & \multirow[t]{2}{*}{$\mathrm{T} 2$} & Department of Biology & \multirow[t]{2}{*}{ Fresh } \\
\hline & & Faculty of Science, Chiang Mai University & \\
\hline \multirow[t]{2}{*}{ Thunbergia laurifolia } & \multirow[t]{2}{*}{ T3 } & Queen Sirikit Botanical Garden & \multirow[t]{2}{*}{ Dry } \\
\hline & & Mae Rim, Chiang Mai (voucher number 46323) & \\
\hline \multirow[t]{2}{*}{ Thunbergia laurifolia } & \multirow[t]{2}{*}{ T4 } & Queen Sirikit Botanical Garden & \multirow[t]{2}{*}{ Dry } \\
\hline & & Mae Rim, Chiang Mai (voucher number 59427) & \\
\hline \multirow[t]{2}{*}{ Crotalaria spectabilis } & \multirow[t]{2}{*}{ C1 } & Materia Medica garden & \multirow[t]{2}{*}{ Fresh } \\
\hline & & Faculty of Pharmacy, Chiang Mai University & \\
\hline \multirow[t]{2}{*}{ Crotalaria spectabilis } & \multirow[t]{2}{*}{ C2 } & Materia Medica garden & \multirow[t]{2}{*}{ Fresh } \\
\hline & & Faculty of Pharmacy, Chiang Mai University & \\
\hline \multirow[t]{2}{*}{ Crotalaria spectabilis } & \multirow[t]{2}{*}{ C3 } & CMU Biology Garden & \multirow[t]{2}{*}{ Fresh } \\
\hline & & Faculty of Science, Chiang Mai University & \\
\hline Commercial CN-C & COM1 & Chiang Mai & Capsule \\
\hline Commercial TT-C & $\mathrm{COM} 2$ & Chiang Mai & Capsule \\
\hline Commercial HBO-C & COM3 & Chiang Mai & Capsule \\
\hline Commercial HBO-T & COM4 & Chiang Mai & Tea bag \\
\hline Commercial APB-P & COM5 & Lamphun & Powder \\
\hline Commercial NK-L & COM6 & Lamphun & Dried leaf \\
\hline Commercial GT-L & COM7 & Pa Yao & Dried leaf \\
\hline Commercial OTOP-T & COM8 & Pa Yao & Tea bag \\
\hline Commercial RTN-S1 & COM9 & Pa Yao & Dried bark \\
\hline Commercial RTN-S2 & COM10 & Pa Yao & Dried bark \\
\hline
\end{tabular}

Sirikit Botanic Garden (QSBG). The plant material was ground with liquid nitrogen, and then used for DNA extraction with the Nucleospin Plant ${ }^{\oplus}$ II kit (MachereyNagel, Germany) following the manufacturer's instruction. DNA concentrations of all samples were equally adjusted (20 ng/ $\mu \mathrm{L}$ ). The DNA was stored at $-20^{\circ} \mathrm{C}$ for further use.

\section{Real-time PCR amplification and high resolution melting (HRM) analysis}

To determine the characteristic melting temperature $\left(T_{m}\right)$ for each sample that could be used to distinguish the two different 'Rang Chuet' medicinal plants, PCR amplification, DNA melting, and end point fluorescence level acquiring PCR amplifications were performed in a total volume of $20 \mu \mathrm{L}$ on an Eco ${ }^{\mathrm{Ts}}$ Real-Time PCR system (Illumina ${ }^{\oplus}$, San Diego, USA). The reaction mixture contained $10 \mathrm{ng}$ genomic DNA, $10 \mu \mathrm{L}$ of MeltDoctor ${ }^{\mathrm{Tm}}$ HRM Master Mix (Applied Biosystems, California, USA), $0.2 \mu \mathrm{L}$ of $10 \mathrm{mM}$ forward and reverse primers. The four pairs of candidate barcoding primers nucleotide composition are shown in Table 2. The real-time PCR reaction conditions are as following; an initial denaturing step at $95{ }^{\circ} \mathrm{C}$ for $5 \mathrm{~min}$ followed by 35 cycles of
$95{ }^{\circ} \mathrm{C}$ for $30 \mathrm{~s}, 57^{\circ} \mathrm{C}$ for $30 \mathrm{~s}$, and $72{ }^{\circ} \mathrm{C}$ for $20 \mathrm{~s}$. Subsequently, the PCR amplicons were denatured for HRM at $95{ }^{\circ} \mathrm{C}$ for $15 \mathrm{~s}$, and then annealed at $50{ }^{\circ} \mathrm{C}$ for $15 \mathrm{~s}$ to form random DNA duplexes. Melting curves were generated after the last extension step. The temperature was increased from 60 to $95{ }^{\circ} \mathrm{C}$ at $0.1{ }^{\circ} \mathrm{C} / \mathrm{s}$. The melting curves were analyzed with the $\mathrm{Eco}^{\mathrm{Tm}}$ software (version 4.0.7.0). After obtaining the suitable primers for the HRM in order to test the sensitivity of the developed

Table 2 Four primers used for HRM analysis and identification

\begin{tabular}{llcc}
\hline Primer name & Nucleotide sequence $\left(5^{\prime}\right.$ to $\left.3^{\prime}\right)$ & $T_{a}\left({ }^{\circ} \mathrm{C}\right)$ & $\begin{array}{c}\text { Expected } \\
\text { size }(\mathrm{bp})\end{array}$ \\
\hline matK_F & CTTCTTATTTACGATTAACATCTTCT & 57 & 160 \\
matK_R & TाTCCTTGATATCGAACATAATG & & \\
rbcL_F & GGTACATGGACAACTGTGTGGA & 57 & 150 \\
rbcL_R & ACAGAACCTTCTTCAAAAAGGTCTA & & \\
rpoC_F & CCSATTGTATGGGAAATACT & 57 & 170 \\
rpoC_R & CTTACAAACTAATGGATGTAA & & \\
trnL_F & GAATCGACCGTTCAAGTATCC & 57 & 150 \\
trnL_R & TATAGGAAACCCATATTTGATCCAATC & & \\
\hline
\end{tabular}


method, real-time PCR and barcoding with HRM were carried out on standard samples, prepared by mixing fine powder of T. laurifolia with C. spectabilis in different proportions of $1,3,6,12,25$, and $50 \%$. Real-time PCR amplification was performed as described earlier.

\section{Authenticating test of herbal products sold on Thai local markets}

Ten herbal products labeled as 'Rang Chuet' were purchased for this study. All of the products were acquired in processed forms (Table 1). Total DNA was extracted from each sample and then used in HRM analysis in order to identify the characteristic melting temperature $\left(\mathrm{T}_{\mathrm{m}}\right)$.

\section{Results and discussion}

\section{Data mining and primers used}

The amplification of the four selected locus from two 'Rang Chuet' medicinal plant species (T. laurifolia and C. spectabilis) was performed using specific primers corresponding to the matK, $r b c L, r p o C$ and $\operatorname{trn} L$ barcode region. All sequences of Thunbergia spp. were extracted from GenBank and the variable characters and average \%GC content was calculated for all samples (Table 3). Data was present for most markers of the target species, except for rpoC. The total number of sequences retrieved for the respective markers were: matK 11 (7 species); $r b c L 6$ (6 species), trnL 27 (20 species). The absence of $r p o C$ sequences for the target species was resolved by selecting random rpoC sequences from GenBank, which is supported by the high universality of rpoC $[17,22]$. Two sequences of $C$. spectabilis were retrieved (matK and trnL).

For matK 5, rbcL 6, rpoC 5 and trnL 19 sequences were deemed useful for further analysis (Table 4). An alignment of all useful sequences was made, and the primers flanking regions of each marker ranging from 150 to $170 \mathrm{bp}$ were analyzed (Table 2). Reed and Wittwer [23] found that suitable length for HRM analysis should be $300 \mathrm{bp}$ or less for optimal results.

Both the sequence length and the nucleotide variation within sequences influence the dissociation energy of the base pairs and result in different $\mathrm{T}_{\mathrm{m}}$ values. The matK amplicon sequences were observed to have higher nucleotide variation than the amplicons of the other regions, at $30.67 \%$. The relative nucleotide variation within amplicons was found to be as follows: matK > $r p o C>\operatorname{trn} L>r b c L$ (Table 3). The forward and reverse matK primers matched the consensus sequence of the target species at the binding sites in only 15 out of 26 sites $(57.69 \%)$ and 19 out 23 of sites (82.61\%), respectively (Table 3 ). High universality at the initial bases of the primer site is crucial for primer annealing and subsequent elongation initiation by the DNA polymerase. The mat $K$ locus is one of the most variable plastid coding regions and has high interspecific divergence and good discriminatory power. However, it can be difficult to amplify with the standard barcoding primers due to high substitution rates at the primer sites [24, 25]. The $r b c L$, $r p o C$ and $\operatorname{trn} L$ primer pairs were expected to be a suitable primer for HRM analysis for discrimination between the tested plant species. These primers were nearly identical in base similarity to the mined consensus sequence (Table 3 ).

The average \%GC content of amplicons was calculated in order to predict variation in melting curves for the different markers. trnL had the lowest average \%GC content, with $34.50 \%$, followed by matK, rpoC and $r b c L$, with $35.20,41.85,44.26$ and $46.60 \%$ respectively (Table 3).

\section{Finding suitable primer pairs for discrimination between T. laurifolia and C. spectabilis}

The four primers sets were used for the amplification of DNA-fragments from all seven samples (two 'Rang Chuet' species), and the amplicons were analyzed using HRM to define $\mathrm{T}_{\mathrm{m}}$. (Table 5). The expected length of amplified products from matK, $r b c L, r p o C$, and $\operatorname{trn} L$ are $160 \mathrm{bp}, 150 \mathrm{bp}, 170 \mathrm{bp}$, and $150 \mathrm{bp}$, respectively. The melting profiles of all amplicons are illustrated in Fig. 1a-1d. The analysis is presented by means of conventional derivative plots, which show that the $T_{m}$ value of each species is represented by a peak. The samples of the two different species could be easily distinguished using HRM analysis with all four primer pairs. The melting profiles of seven samples of the two 'Rang Chuet' species (T. laurifolia and C. spectabilis) can be divided into two groups. All T. laurifolia samples (T1-T4) are grouped together and the other group contains all C. spectabilis samples (C1-C3). Although

Table 3 Characteristics of sequences and primers for high resolution melting analysis

\begin{tabular}{|c|c|c|c|c|}
\hline Regions & matk & $r b c L$ & rpoc & $\operatorname{trnL}$ \\
\hline Available species & 5 & 6 & 5 & 19 \\
\hline Variable characters (\%) & 30.67 & 10.07 & 10.19 & 8.90 \\
\hline Conserved forward primer/total (\%) & $15 / 26(57.69)$ & $21 / 22(95.45)$ & $18 / 21(85.71)$ & $19 / 21(90.48)$ \\
\hline Conserved reverse primer/total (\%) & $19 / 23(82.61)$ & $25 / 25(100)$ & $19 / 21(90.48)$ & $24 / 27(88.89)$ \\
\hline Average \%GC content & 35.20 & 46.60 & 44.26 & 34.50 \\
\hline
\end{tabular}


Table 4 Sequences of four plastid regions ( $m a t K, r b c L, r p o C$ and $\operatorname{trn} L)$ were retrieved from GenBank (NCBI) for each of the species with accession number

\begin{tabular}{|c|c|c|c|c|}
\hline \multirow[t]{2}{*}{ Species } & \multicolumn{4}{|l|}{ Regions } \\
\hline & $\operatorname{trnL}$ & matK & $r b c L$ & rpoC \\
\hline Crotalaria spectabilis & HM208335 & AB649973 & - & - \\
\hline \multirow[t]{2}{*}{ Thunbergia affinis } & AB817377 & - & - & - \\
\hline & EU315886 & & & \\
\hline \multirow[t]{3}{*}{ Thunbergia alata } & AF061820 & HQ384512 & HQ384878 & - \\
\hline & EU529130 & AF531811 & & \\
\hline & EU315887 & & & \\
\hline Thunbergia angulata & EU315888 & - & - & - \\
\hline Thunbergia arnhemica & EU315889 & - & - & - \\
\hline Thunbergia atriplicifolia & EU315890 & - & - & - \\
\hline Thunbergia battiscombei & EU315891 & - & - & - \\
\hline Thunbergia capensis & EU315892 & AM234783 & AM234783 & - \\
\hline Thunbergia coccinea & EU529131 & HG004920 & KF181493 & - \\
\hline Thunbergia convolvulifolia & EU315894 & - & - & - \\
\hline Thunbergia dregeana & EU315895 & - & - & - \\
\hline \multirow[t]{4}{*}{ Thunbergia erecta } & AF061821 & AB649972 & - & - \\
\hline & JQ764614 & & & \\
\hline & EU529132 & & & \\
\hline & EU315896 & & & \\
\hline Thunbergia fragrans & U315897 & - & - & - \\
\hline Thunbergia galpinii & EU315898 & - & - & - \\
\hline \multirow[t]{4}{*}{ Thunbergia grandiflora } & EU315899 & AB649971 & JQ590086 & - \\
\hline & & JQ586429 & & \\
\hline & & JQ586428 & & \\
\hline & & JQ586427 & & \\
\hline Thunbergia gregoryi & EU315901 & - & - & - \\
\hline Thunbergia guerkeana & EU315901 & - & - & - \\
\hline Thunbergia kirkii & EU315902 & - & - & - \\
\hline Thunbergia laurifolia & - & AB649970 & - & - \\
\hline Thunbergia mysorensis & - & - & AY008828 & - \\
\hline Thunbergia petersiana & EU315904 & - & - & - \\
\hline Thunbergia pondoensis & EU315905 & - & - & - \\
\hline Thunbergia togoensis & EU315906 & - & - & - \\
\hline Thunbergia usambarica & - & - & L12596 & - \\
\hline
\end{tabular}

the four primer pairs tested could be used to discriminate $T$. laurifolia from $C$. spectabilis, the rpoC region was chosen for further analysis as it would help in demonstrating that Bar-HRM could work well as a sequencing-free method for plant identification. In addition, the rpoC region was used as an analytical target in HRM analysis has been shown to be effective for the detection and quantification of Lens culinaris and Lathyrus clymenum adulterations [18, 22].

\section{Quantitative detection of $T$. laurifolia adulterants with Bar-HRM analysis}

Detecting limit of adulteration in T. laurifolia products using the developed method with rpoC primers was tested. Figure 2a shows the results of the validation method with $T$. laurifolia spiked with $C$. spectabilis in different proportions. These results depict the analysis for one experiment as all three experiments gave similar results thus showing very good reproducibility. The process of the T. laurifolia amplicon dissociation reveals the level of contamination resulting from adulteration as the presence of increasing quantity of $C$. spectabilis into the $T$. laurifolia DNA alters the shape and shifts proportionally the melting curve, compared to the curve of pure T. laurifolia DNA. By applying this approach, we were able to detect adulterations as low as $1 \%$ (Fig. 2a).

\section{Identification of herbal species in commercial products}

Constituent species in herbal products bought from markets in Thailand were investigated to assess the reliability of information regarding their ingredients, as the herbal products are often sold in processed forms. Ten herbal products labeled as 'Rang Chuet' were purchased and examined (Table 1). The HRM analysis using rpoC primers was then performed to identify the species in the products.

The examination of the HRM difference curve of all tested samples using $T$. laurifolia curve as baseline revealed that seven out of ten samples (COM3-7 and 9-10) produce curves in which the same as T. laurifolia's with a $90 \%$ confidence interval, suggesting that the products contain T. laurifolia (Fig. 2b). The melting curve of one tested sample (COM8) was found between T. laurifolia and $C$. spectabilis lines, it could be indicated that the commercial COM8 was probably be admixture of T. laurifolia and $C$. spectabilis with around 3\% of the toxic C. spectabilis in the product as show in Fig. 2b. However, we cannot rule out the possibility of the COM8 may actually not be contaminated with the toxic C. spectabilis but other species. In addition, the results of the analysis also reveal that the two remaining samples (COM1 and COM2) were much likely not contain any of the two 'Rang Chuet' species but some other species instead (Fig. 2b). In order to find contaminated or substituted species in COM1 and COM2, DNA barcoding is one of the best solutions. As can be seen from Newmaster et al [26] work, DNA barcoding was performed to detect the adulteration and substitution of herbal drugs and found that herbal products sold on the markets were contaminated or substituted with alternative plant species that are not listed on the labels as they are replaced entirely by powdered rice, wheat and soybean. Thus, DNA sequencing of $r b c L$ region was carried out to identify species in these two products. The blast result showed that COM1 and COM2 have a similarity in their 
Table 5 The values of melting temperature $\left({ }^{\circ} \mathrm{C}\right)$ with standard deviations gaining form high resolution melting (HRM) analysis using matK, rbcL, rpoC and trnL primers of T. laurifolia and C. spectabilis species

\begin{tabular}{|c|c|c|c|c|c|}
\hline \multirow[t]{2}{*}{ Species } & \multirow[t]{2}{*}{ Abbreviation } & \multicolumn{4}{|l|}{$\operatorname{Tm}\left({ }^{\circ} \mathrm{C}\right)$} \\
\hline & & matK & $r b c L$ & rpoC & $\operatorname{trnL}$ \\
\hline T. laurifolia & $\mathrm{T} 1$ & - & $82.5 \pm 0.07$ & $80.2 \pm 0.12$ & $78.8 \pm 0.07$ \\
\hline T. laurifolia & $\mathrm{T} 2$ & - & $82.4 \pm 0.14$ & $80.1 \pm 0.15$ & $78.9 \pm 0.07$ \\
\hline T. laurifolia & T3 & $77.9 \pm 0.35$ & $82.3 \pm 0.14$ & $80.2 \pm 0.00$ & $78.8 \pm 0.00$ \\
\hline T. laurifolia & T4 & - & $82.4 \pm 0.07$ & $80.2 \pm 0.07$ & $78.8 \pm 0.14$ \\
\hline C. spectabilis & $\mathrm{C} 1$ & $75.6 \pm 0.21$ & $81.6 \pm 0.00$ & $80.9 \pm 0.06$ & $78.4 \pm 0.14$ \\
\hline C. spectabilis & $C 2$ & $75.3 \pm 0.07$ & $81.6 \pm 0.07$ & $80.9 \pm 0.06$ & - \\
\hline C. spectabilis & C3 & $75.4 \pm 0.21$ & $81.5 \pm 0.00$ & $80.8 \pm 0.00$ & $78.2 \pm 0.00$ \\
\hline
\end{tabular}

(-) No amplicons were generated

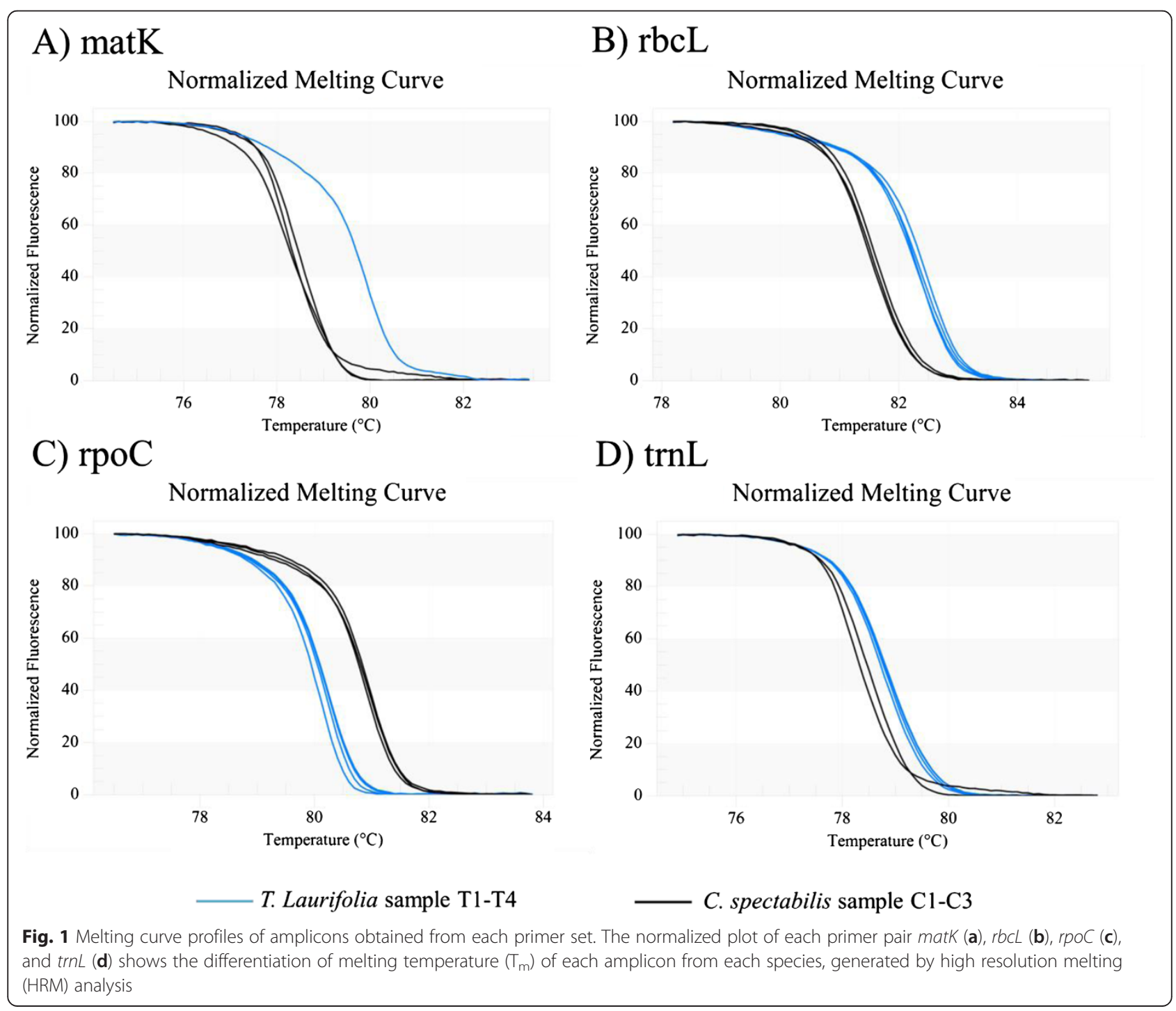




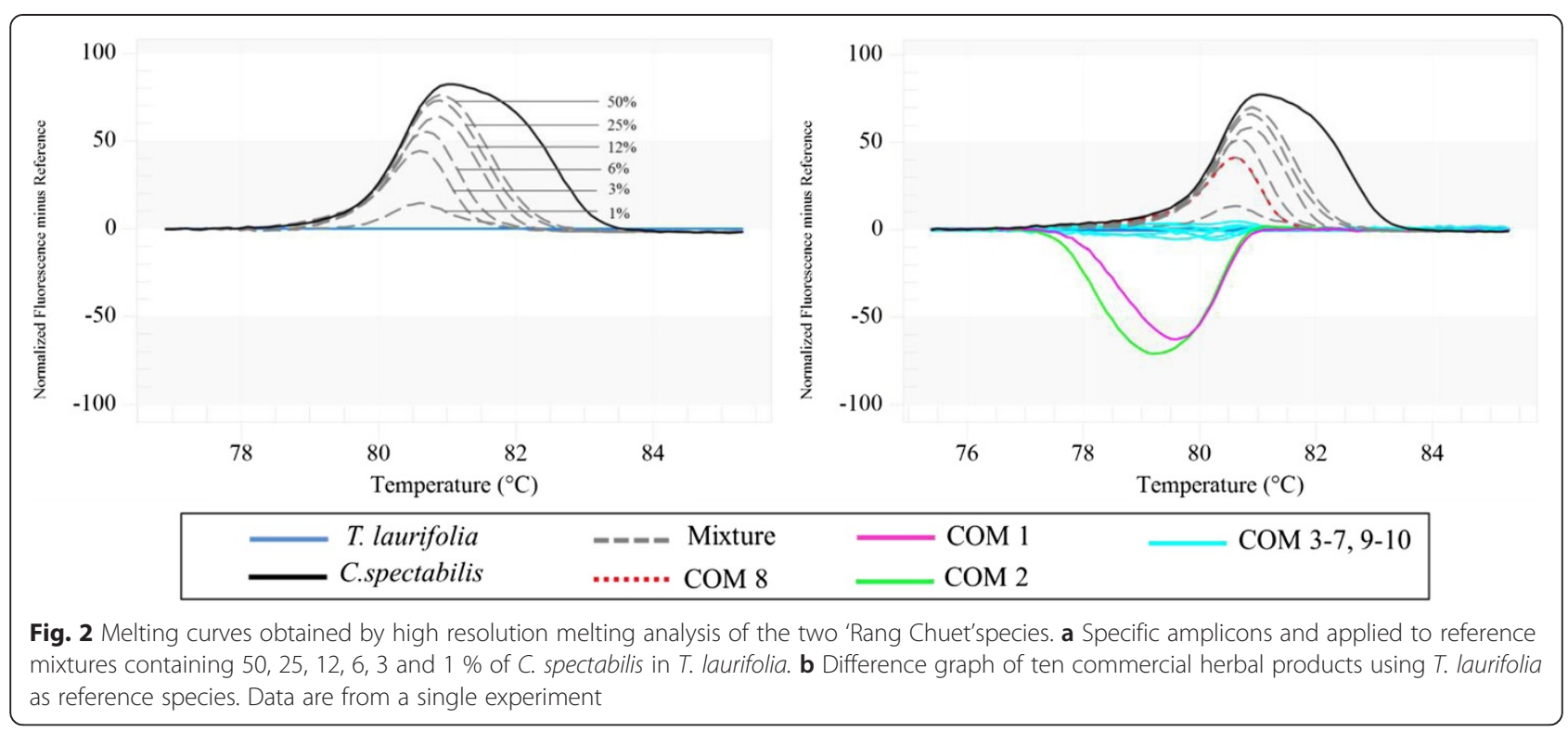

sequences to Moringa oleifera and Andrographis paniculata, respectively (Additional file 1: Table S1). The finding provides evidence that substitution in herbal products sold Thai local market is presented and this substitution could be a serious issue for consumers. Due to the fact that BarHRM has allowed us easily determine herbal species in processed products sold on the markets within $2 \mathrm{~h}$. BarHRM method developed in this study therefore pose a potential to be a great tool in detection of adulteration and/ or substitution in herbal products especially in processed forms.

\section{Conclusions}

Several studies have shown that substitution of plant species occurs in herbal medicines, and this in turn poses a challenge to herbal authentication as adverse reactions might be due to substituted ingredients. BarHRM has proven to be a cost-effective and reliable method for the identification of species in this study of Thai medicinal plants. The hybrid method of DNA barcoding and High Resolution Melting is dependable, fast, and sensitive enough to distinguish between species. In this study, the tested products were traded as processed powder, which impedes conventional identification. Because of this processing it is almost impossible to identify which herbal species are present in products using morphological characters. The DNA extracted from all products tested yielded a specific amplification product with the designed rpoC Bar-HRM primers. The normalized HRM curves for the amplicons, from the two 'Rang Chuet' species (T. laurifolia and the toxic C. spectabilis) and ten herbal products, based on HRM analysis with barcode marker rpoC were easily distinguished, and seven of the ten tested samples were successfully assigned to the $T$. laurifolia species. However, three products were found to contain other plant species or admixture of the two 'Rang Chuet' species. Therefore, the developed method could be easily used for rapid and low-cost authentication of herbal products. Interestingly, designing primer for HRM analysis commonly depends on information in database but here even none of $r p o C$ sequences of Thunbergia could be found on the database, the rpoC primer pair derived from DNA data of other random medicinal plant species is found to be work well in this analysis. It is demonstrated that this method has not only shown the great beneficial value for universality test which might be useful in other medicinal species but also flexibility using DNA region with limited data like rpoC.

\section{Additional file}

Additional file 1: Table S1. Blast results of two commercial product rbcl sequences.

\section{Competing interests}

The authors declare that they have no competing interests.

\section{Authors' contributions}

MO planned the study; SS and MO collecting the plant materials, performed the study and conducted the data analysis; MO prepared data for the additional supporting file; SS and MO wrote the manuscript; MO thoroughly revised the manuscript; Both authors discussed the results and approved the final manuscript.

\section{Acknowledgements}

This research was financially supported by CMU Junior Research Fellowship Program and New Researcher Grant from the Thailand Research Fund (grant number TRG5780027) awarded to MO. We would like to thank Queen Sirikit Botanical Garden in Mae Rim, Chiang Mai Thailand for allowing us accessing dry samples for using in this experiment. 
Received: 30 October 2014 Accepted: 22 May 2015

Published online: 30 May 2015

\section{References}

1. Kunle OF, Egharevba HO, Ahmadu PO. Standardization of herbal medicines - A review. IJBC. 2012;4(3):101-12.

2. Oreagba IA, Oshikoya KA, Amachree M. Herbal medicine use among urban residents in Lagos, Nigeria. BMC Complement Altern Med. 2011;11:117.

3. Chan EWC, Lim YY. Antioxidant activity of Thunbergia laurifolia tea. JTFS. 2006;18:130-6.

4. Suwanchaikasem P, Chaichantipyuth C, Amnuoypol S, Sukrong S. Random amplified polymorphic DNA analysis of Thunbergia laurifolia Lindl. and its related species. JMPR. 2012;6:2955-61.

5. Suwanchaikasem P, Phadungcharoen T, Sukrong S. Authentication of the Thai medicinal plants sharing the same common name 'Rang Chuet': Thunber gia laurifolia, Crotalaria spectabilis, and Curcuma aff. amada by combined techniques of TLC, PCR-RFLP fingerprints, and antioxidant activities. ScienceAsia. 2013;39:124-33.

6. Chan EWC, Eng SY, Tan YP, Wong ZC. Phytochemistry and pharmacological properties of Thunbergia laurifolia: A Review. Phcogj. 2011;3:1-6.

7. Flores AS, de Azevedo Tozzi AMG, Trigo JR. Pyrrolizidine alkaloid profiles in Crotalaria species from Brazil: Chemotaxonomic significance. Biochem Syst Ecol. 2009;37:459-69.

8. Leverett LD, Woods M. The Genus Crotalaria (Fabaceae) in Alabama. Castanea. 2012;77:364-74.

9. Schultze $A E$, Roth RA. Chronic pulmonary hypertension-the monocrotaline model and involvement of the hemostatic system. J Toxicol Environ Health B Crit Rev. 1998;1:271-346.

10. Wonkchalee O, Boonmars T, Aromdee C, Laummaunwai C, Khunkitti W, Vaeteewoottacharn K, Sriraj P, Aukkanimart R, Loilome W, Chamgramol Y, Pairojkul C, Wu Z, Juasook A, Sudsarn P. Anti-inflammatory, antioxidant and hepato protective effects of Thunbergia laurifolia Linn. on experimental opisthor chiasis. Parasitol Res. 2012;111:353-9.

11. Prenner GA, Bush A, Wise R, Kim W, Dommier L, Kasha K, Laroche A, Scoles G, Molnar SJ, Fedak G. Reproducibility of random amplified polymorphic DNA (RAPD) analysis among laboratories. Genome Res. 1993;2:341-5.

12. Yang $X$, Quiros C. Identification and classification of celery cultivars with RAPD markers. Theor Appl Genet. 1993;86:205-12.

13. Qiu JJ, Li YP. Random amplified polymorphic DNA analysis of eel genome. Cell Res. 1999;9:217-23.

14. Carvalho VP, Ruas CF, Ferreira JM, Moreira RMP, Ruas PM. Genetic diversity among maize (Zea mays L.) landraces assessed by RAPD Markers. Genet Mol Biol. 2004;27:228-36.

15. Techen N, Parveen I, Pan Z, Khan IA. DNA barcoding of medicinal plant material for identification. Current Opinion In Biotech. 2014;25:103-10.

16. von Crautlein M, Korpelainen $H$, Pietilainen M, Rikkinen J. DNA barcoding: a tool for improved taxon identification and detection of species diversity. Biodivers Conserv. 2011;20:373-89.

17. Kress WJ, Wurdack KJ, Zimmer EA, Weigt LA, Janzen DH. Use of DNA barcodes to identify flowering plants. PNAS. 2005;102(23):8369-74.

18. Ganopoulos I, Madesis P, Darzentas N, Argiriou A, Tsaftaris A. Barcode High Resolution Melting (Bar-HRM) analysis for detection and quantification of PDO "Fava Santorinis" (Lathyrus clymenum) adulterants. Food Chem. 2012;133:505-12.

19. Jaakola L, Suokas M, Haggman H. Novel approaches based on DNA barcoding and high-resolution melting of amplicons for authenticity analyses of berry species. Food Chem. 2010;123:494-500.

20. Sakaridis I, Ganopoulos I, Argiriou A, Tsaftaris A. A fast and accurate method for controlling the correct labeling of products containing buffalo meat using High Resolution Melting (HRM) analysis. Meat Sci. 2013;94:84-8.

21. Tamura K, Stecher G, Peterson D, Filipski A, Kumar S. MEGA6: Molecular Evolutionary Genetics Analysis Version 6.0. Mol Biol Evol. 2013;30:2725-9.

22. Kool M, Korshunov A, Remke M, Jones DTW, Schlanstein M, Northcott PA, Cho YJ, Koster J, Schouten-van Meeteren A, van Vuurden D, Clifford SC, Pietsch T, von Bueren AO, Rutkowski S, McCabe M, Collins VP, Backlund ML, Haberler C, Bourdeaut F, Delattre O, Doz F, Ellison DW, Gilbertson RJ, Pomeroy SL, Taylor MD, Lichter P, Pfister SM. Molecular subgroups of medulloblastoma: an international meta-analysis of transcriptome, genetic aberrations, and clinical data of WNT, SHH, Group 3, and Group 4 medulloblastomas. Acta Neuropathol. 2012;123:473-84.
23. Bosmali I, Ganopoulos I, Madesis P, Tsaftaris A. Microsatellite and DNA-barcode regions typing combined with high resolution melting (HRM) analysis for food forensic uses: a case study on lentils (Lens culinaris). Food Res Int. 2012;46:141-7.

24. CBOL Plant Working Group. A DNA barcode for land plants. Proc Natl Acad Sci. 2009;106:12794-7.

25. Hollingsworth PM. Refining the DNA barcode for land plants. Proc Natl Acad Sci. 2011;108:19451-2.

26. Newmaster SG, Grguric M, Shanmughanandhan D, Ramalingam S, Ragupathy S. DNA barcoding detects contamination and substitution in North American herbal products. BMC Med. 2013;11:222.

\section{Submit your next manuscript to BioMed Central and take full advantage of:}

- Convenient online submission

- Thorough peer review

- No space constraints or color figure charges

- Immediate publication on acceptance

- Inclusion in PubMed, CAS, Scopus and Google Scholar

- Research which is freely available for redistribution 